\title{
CAN THE USE OF ENGLISH AS A MEDIUM OF \\ INSTRUCTION PROMOTE A MORE INCLUSIVE AND EQUITABLE HIGHER EDUCATION IN BRAZIL?
}

\author{
LAURA BAUMVOL \\ Simon Fraser University \\ University of British Columbia \\ Federal University of Rio Grande do Sul (UFRGS) \\ SIMONE SARMENTO \\ Federal University of Rio Grande do Sul (UFRGS)
}

\begin{abstract}
In this paper, we present the status quo and challenges regarding the use of additional languages as a medium of instruction in Brazilian higher education. We begin by contextualizing the importance of the process of internationalization at home $(\mathrm{IaH})$ and additional languages in higher education. Next, the teaching of additional languages in Brazil, which has been until very recently relegated to the private sector and accessible only to an elite, is introduced. We then provide an overview of the present state of affairs of English as a Medium of Instruction (EMI) in the country, which is still in its infancy. We move on to describe different ways in which language and content can be integrated in higher education, as well as how EMI can be introduced in disciplinary courses. We finish concluding that EMI can maximize the learning of academic English by Brazilian students and content instructors, as well as encourage a more international higher education and balanced academic mobility by allowing foreign students to study in Brazil while preserving and even increasing the international interest in the Portuguese language. In a country located in the periphery of knowledge production and dissemination, we understand that the adoption of EMI can potentially foster the inclusion of more Brazilians in the global academic and research scenario. It gives them access to the knowledge produced internationally and, at the same time, enables the research produced in the country to be disseminated globally.
\end{abstract}

Keywords: internationalization at home, additional languages, English as a medium of instruction 


\section{Introduction}

The contribution of higher education (HE) to poverty eradication, sustainable development, and global progress has been highlighted in official documents issued by the United Nations, such as the Millennium Development Goals (MDG) and Education for All (EFA). In the 2009 World Conference on Higher Education organized by UNESCO, participants prepared an official announcement based on the results and recommendations of the six regional conferences previously held ${ }^{1}$. The guiding principles of the announcement were: social responsibility of $\mathrm{HE}$; access, equity and quality; internationalization, regionalization and globalization; and learning, research and innovation (UNESCO, 2009). With regards to internationalization, the document specified the following items, among others:

\begin{tabular}{l|l}
\hline 1 & Promotion of international cooperation in $\mathrm{HE}$, based on solidarity and mutual respect. \\
\hline 2 & $\begin{array}{l}\text { The role of international university networks and partnerships to enhance mutual understanding and } \\
\text { a culture of peace. }\end{array}$ \\
\hline $\mathbf{3}$ & $\begin{array}{l}\text { The encouragement of a more equitable academic mobility to guarantee genuine multilateral and } \\
\text { multicultural collaboration. }\end{array}$ \\
\hline $\mathbf{4}$ & $\begin{array}{l}\text { The creation of national knowledge capabilities in all involved countries to ensure more diversified } \\
\text { sources of high quality knowledge production, on regional and global scales. }\end{array}$ \\
\hline $\mathbf{5}$ & $\begin{array}{l}\text { Equal access to quality education for all, respecting cultural diversity, as well as national sovereignty. } \\
\mathbf{6}\end{array}$ \\
$\begin{array}{l}\text { The contribution of cross-border provision of HE to promote quality education and academic values, } \\
\text { to maintain basic principles of dialogue and cooperation, mutual recognition, and respect for human } \\
\text { rights, diversity and national sovereignty. }\end{array}$
\end{tabular}

Table 1. Items from the 2009 World Conference on Higher Education Final Report. Adapted from UNESCO (2009).

As a result of the United Nations and UNESCO guidelines, in the last decades, public policies for post-secondary education in Brazil have focused on achieving an inclusive university of excellence, involving actions towards democratization of access, improvement of faculty qualification and expansion of graduate programs, as shown by goals 12, 13 and 14 of the National Education Plan (NEP)² (Ministério da Educação e Cultura [MEC], 2014a) (Sarmento, Abreu-e-Lima, \& Moraes, 2016). Public HE has always been entirely free in the country and until 2016 there were substantial investments in educational policies to promote inclusion, excellence and internationalization (ANDIFES, 2012; MEC, 2014a).

In 2007, the implementation of a program focused on the restructuring of federal universities (REUNI) triggered an unprecedented expansion in public HE. Based on the program, the Association of Directors of Federal Higher Education Institutions (ANDIFES) designed guidelines for the expansion, excellence and internationalization of federal universities

\footnotetext{
${ }^{1}$ Cartagena de Indias; Macao; Dakar; New Delhi; Bucharest; and Cairo.

${ }^{2}$ For the purpose of translation, Plano Nacional de Educação (PNE) has been modified to National Education Plan (NEP) in this document.
} 
(ANDIFES, 2012). These guidelines indicate the need for institutions' academic adjustment to new demands and global contexts; skilled labor strategic training due to the new social and economic conjunctures; the country's insertion into the new world order of knowledge through the production of science, technology and innovation; and of greater knowledge production and dissemination for the promotion of equality, inclusion and development of responsible citizens (ANDIFES, 2012).

A crucial step for the accomplishment of PNE Goals 13 and 14 (MEC, 2014b) and ANDIFES Guidelines (ANDIFES, 2012) was the implementation of the Science without Borders Program (SwB) in 2011 (Ministério da Ciência, Tecnologia e Inovação [MCTI], 2011), whose goal was the consolidation, expansion, and internationalization of science and technology for the country's sustained development through large scale international mobility of HE students. From 2011 until its discontinuation in 2016, SwB focused on promoting the opportunity for new educational and professional experiences focused on quality, entrepreneurship, competitiveness and innovation in fields considered priority and strategic for Brazil (MEC, 2014b). The Program accomplished an expansion of international outbound mobility of mostly undergraduate students, reaching approximately 93,000 Brazilian students who experienced a variety of cultural, scientific and educational opportunities in different contexts around the globe ${ }^{3}$. However, SwB faced huge hindrances as far as proficiency in the English language is concerned. In the first editions of the Program, most students opted to go to universities in countries whose language of instruction was familiar to Brazilians, i.e., Portugal. For this reason, Portugal was cut out as a destination and students had to be redirected to other countries and were sent abroad for an extra semester to learn English prior to their academic programs.

This paper discusses the role of Additional Languages (ALs), particularly the English language, in the internationalization of post-secondary education, and particularly in Brazil. It addresses the different terminologies adopted by international literature to refer to relatively similar models of content-based instruction, as well as the nuances of content-based teaching and learning and English as a Medium of instruction (EMI) approaches.

\section{Internationalization at Home and Additional Languages}

As the seminal work of Knight (2008) demonstrates, different driving forces are involved in the internationalization of educational institutions. For instance, in North American and European countries, social and academic rationales do not always seem to be the main factors, given the strong commercial and market features of HE (Kubota, 2009). In these contexts, attracting foreign students to pay much higher tuition fees than local students has been an explicit and major goal of universities (Garson, 2016) and, consequently, rationales as generation of revenue, the search for financial incentives, and the positioning in international rankings have become preponderant.

In Brazil, however, the process of internationalization takes on a distinct dimension since

\footnotetext{
${ }^{3}$ A series of criticisms on the SwB were made regarding the lack of indicators to evaluate the program, the high cost of English classes for students who did not have the required English proficiency level, among others.
} 
no tuition is charged in public HE, either for Brazilians or for foreigners. Tuition-free education allows for the emphasis to be placed on the establishment of equitable networks and partnerships between different nations, the qualification of knowledge production in the country, the pursuit of balanced inbound and outbound academic mobility, and more equal access to international practices. Despite the remarkable progress in recent years, especially due to Science without Borders (SwB) program (MCT, 2011), internationalization is still at an incipient stage in Brazil.

Traditionally, academic mobility - defined as a period of study, teaching and/or research in a country other than someone's home country - has been perceived as the only or the most important instrument of internationalizing HE. Over the last two decades, however, academic mobility has started to be part of a broader internationalization process, due to the development of the Bologna process that led to the signature of the Bologna Declaration by 29 countries ${ }^{4}$ (European Union, 2009). This is a collective effort of public authorities, universities, stakeholder associations, employers, international agencies and organisations, including the European Commission, to strengthen the quality assurance of European education and to simplify the recognition of qualifications and periods of study among different countries (European Union, 2009). However, access to international experiences is only available to a small minority of those involved in post-secondary education. Recent data from the Organisation for Economic Cooperation and Development expects only $3 \%$ of students, faculty and staff to experience academic mobility by 2025 (OECD, 2016).

There is a significant increase in imbalance in academic mobility among more and less economically developed countries, with very few accounting for the majority of inbound and outbound flow of students (Egron-Polak, 2017). The United States, the United Kingdom and Canada are countries that receive the greatest number of foreign students, while Brazil and other nations in the Southern hemisphere send far more students abroad. In Brazil, 7,305,977 students were enrolled in undergraduate programs in 2013 (Instituto Nacional de Estudos e Pesquisas Educacionais Anísio Teixeira [INEP], 2013), while the Science without Borders (SwB) program, the most ambitious and comprehensive mobility program ever, offered around 73,000 outbound undergraduate scholarships from 2011 to $2015^{5}$. These numbers show that even the most generous outbound mobility program in history accounted for less than $1 \%$ of the country's undergraduate students' population. Moreover, SwB only managed to attract a little over 1,000 students from other countries unveiling this unfair imbalance in the flow of students, with developing countries having great difficulty in attracting students from developed ones. Now, with the end of SwB, students' mobility in Brazil has decreased exponentially, and the situation does not seem likely to change anytime soon. Also, Brazilian universities have almost no international students. In 2018, there were over 8 million students enrolled in undergraduate programs scattered over 2,400 HE institutions, and only about 10,000 international students, being most of them from Spanish speaking neighbouring countries (Gimenez, Sarmento,

\footnotetext{
${ }^{4}$ Currently, 48 countries participate in the Bologna Process (European Higher Education Area, n.d.).

${ }^{5}$ Although the SwB reached only a few fields of knowledge, these figures illustrate the small number of students who have access to mobility programs.
} 
Archanjo, Zicman, \& Finardi, 2018). Thus, Portuguese ${ }^{6}$ is (nearly) the sole language of instruction, as it will be reported below. As a country of continental dimensions and the only one in the Global South whose main language is Portuguese, Brazil has been left in a kind of academic (and linguistic) isolation. It is not uncommon to encounter professors and students who came back from a mobility program abroad resenting the fact that they do not have opportunities to keep up with the language of the host country, in many cases English, because of lack of opportunities to use the AL.

Hence, if internationalization is a high priority for policy makers and HE institutions, mainly in developing countries, then it must go beyond the system of prioritising only academic mobility and shift to one which benefits a wider audience. Authors such as Teekens (2007), de Wit, Hunter, Howard, \& Egron-Polak (2015), and Beelen and Jones (2015) see the development of a process called Internationalization at Home $(\mathrm{IaH})$ as a counteract to the increased emphasis on academic mobility and an alternative for a more inclusive internationalization process. IaH emphasizes the intercultural and international dimension in the teaching and learning processes and research, extracurricular activities, and the integration of foreign students and teachers into local academic life (Knight, 2008). More recently, de Wit et al. (2015) have added as the purpose of IaH "to enhance the quality of education and research for all students and to make a meaningful contribution to society" (p.29).

Likewise, Beelen and Jones (2015) understand that IaH refers to "the purposeful integration of international and intercultural dimensions into the formal and informal curriculum for all students in domestic learning environments" (p. 69). Therefore, IaH activities do not necessarily involve only a classroom or a university campus, but also the local community. In fact, IaH has been working as a new paradigm for the development of strategic institutional internationalization policies, as it encourages the respect for diversity while developing people "with a cosmopolitan mindset, with communication skills between and across cultures, at home" (Teekens, 2007, p. 6).

Within IaH processes, Additional Languages (AL) play a key role in giving access to students and teachers to international practices while in their own countries and institutions. In a globalized and interconnected world, ALs have become a multifunctional and complex phenomenon which allows individuals to perform actions and connect with each other, with communities and with different cultures (Modern Language Association, 2007).

Using 'additional' rather than 'foreign' considers the contributions of adding a language to the cultural and linguistic repertoire that one already has. Aligning with the guidelines of the International Bureau of Education, an organization associated with UNESCO,

'Additional' applies to all, except, of course, the first language learned. An additional language, moreover, may not be foreign since many people in their country may ordinarily speak it. The term 'foreign' can, moreover, suggest strange, exotic or,

\footnotetext{
${ }^{6}$ Portuguese is one of the official languages of Brazil, widely spoken by most of the population. Aside from Portuguese, the country has also numerous minority languages, including 217 indigenous languages. However, fewer than 40,000 people (or about $0.02 \%$ of the population) speak any of the indigenous languages (Rodrigues, 2005). In 2002, Brazilian Sign Language (Libras) was made an official language too.
} 
perhaps, alien - all undesirable connotations. Our choice of the term 'additional' underscores our belief that additional languages are not necessarily inferior nor superior nor a replacement for a student's first language. (Judd, Tan \& Walberg, 2001, p. 6)

Official documents produced by international organizations (European Parliament, 2006; European Union, 2012; UNESCO, 2014) have acknowledged the importance of multilingualism and ALs in students' educational background ${ }^{7}$. In 2014, the Executive Board of UNESCO declared that multilingualism encourages cooperation among nations through dialogue, tolerance and respect for cultural diversity, recognizing the need to implement LEPs for the integration of young people into international exchanges (UNESCO, 2014). The Member States agreed to promote the teaching of at least two additional languages, in addition to the main language of instruction, to ensure the linguistic and intercultural quality of education and to facilitate academic and professional mobility.

In Brazil, the teaching of additional languages has been relegated to the private sector, with over 6,000 private language courses in the country and with an annual increase of $15 \%$ (Windle \& Nogueira, 2015). There are different types of institutions, covering all price ranges, hence, catering for different social classes, but not all of them. Disadvantaged students may only have access to English classes in regular schools, which, in many scenarios would be good enough, but not in Brazil and causes are manifold. First of all, there is a belief that additional languages are not to be learned in the official regular schools, making teachers demotivated from the start. Second, classes are large and there is usually only one hour of English class a week, making it impossible to acquire fluency. Also, public school teachers are underpaid in the country and, to counterbalance the low salaries, have to take more than one job and work very long hours, leaving no room for professional development. This failure of the regular school system in providing quality AL instruction to all students has been well documented in a book by Lima (2011) entitled "English teaching does not work in public schools? Multiple perspectives". In fact, instruction is a problem not only considering ALs, but first language as well (in the Brazilian case, Portuguese). It is common to hear from working-class students that they are "ashamed to talk to people who have studied, because they don't speak Portuguese correctly" (Bartlett, 2007, p. 554). As Windle and Nogueira (2015) point out, these students believe that if "I don't even speak Portuguese properly, how can I learn English?” (p.188).

As a consequence, the educational practices of ruling-class families "have been marked by a heavy investment in learning English and in international travel to 'first world' destinations for educational purposes since the 1990s." (Windle \& Nogueira, 2015, p.176). In 2017 (as well as in previous years), Brazil was the top source country of students in private language courses in Canada, followed by Japan. This has made Brazil one of the target markets for Languages Canada (Languages Canada, 2017).

\footnotetext{
${ }^{7}$ Recently, the United Nations Secretary-General of the United Nations nominated a specific coordinator for the area of multilingualism in the UN. For more information, see http://www.un.org/sg/multilingualism/index.shtml
} 
In order to make amends for the lack of efficient Language Education Policies ${ }^{8}$ in primary and secondary schools, the government launched an AL program in 2012 (MEC, 2012a). The program was first called English without Borders and renamed Languages without Borders (LwB) in 2014 (Sarmento, Abreu-e-Lima, \& Moraes, 2016), comprising six other AL. LwB originated from demands of the Science without Borders ( $\mathrm{SwB}$ ) program and caused an unprecedented change in the teaching of ALs in the country's HE system, offering free tuition for distance and face-to-face courses, as well as large-scale administration of proficiency tests to students, faculty and staff of public post-secondary institutions (MEC, 2012b).

Along with LwB actions, a relatively new phenomenon started to take place in Brazilian HEIs: classes in which the medium of instruction is not Portuguese, but an AL (in most cases English). We acknowledge that the supremacy of English has had negative effects in the status of other home and minority languages around the globe (Kubota, 2018). However, we will demonstrate that the Brazilian context has its own peculiarities, and the use of English can actually have a positive impact when fighting linguistic and social inclusion in the country.

\section{Content-based instruction}

The importance of ALs, especially English, in post-secondary education is not a novelty. Universities around the globe, including the ones located in English-speaking countries have offered English for Academic Purposes (EAP) courses for quite some time:

The field of EAP has blossomed over the past two decades, largely due to the increase in students studying at English-medium universities, as well as the increase of English in scholarly publication, though not without controversy (Kostka \& Olmstead-Wang, 2014, p.2)

EAP is focused solely on the teaching and learning of academic language, more specifically, but not exclusively, on reading and writing skills and courses are taught by EAP tutors, or English teachers who specialize in academic language. This is usually not discipline specific, i.e., students from all areas of knowledge may seat in the same class. However, in the last few years, content and language integrated programs have increased in popularity in non-English dominant countries. Studies in the field of Education and Applied Linguistics use different terms to refer to approaches related to the teaching and learning of content through English or another AL, such as Content and Language Integrated Learning (CLIL) - which is considered as an umbrella term (Airey, 2016), Integrated Content Learning (ICL), Content Based Learning (CBL), Immersion Programs (IP), and for English in particular, English as a Medium of instruction (EMI). These terms allude to relatively similar models of content-based instruction which do not have exact criteria of distinction, nor are they based on different theories of learning, as Dalton-Puffer recalls (2012). Airey (2016) proposes a continuum of content and language approaches, as shown in Figure 2.

\footnotetext{
${ }^{8}$ Cooper (1989) defined Language Education Policies (LEPs) as the "deliberate efforts to influence the behavior of others with respect to the acquisition, structure, or functional allocation of their language codes" (p. 45).
} 


$\begin{array}{ccc}\text { Only language } & \begin{array}{c}\text { Learning outcomes } \\ \text { Language and content }\end{array} & \text { Only content } \\ \text { EAP } & \text { CLIL } \\ \text { Type of course } & \text { EMI }\end{array}$

Figure 1. The language/content continuum. Reprinted from Airey (2016, p. 73).

On the left end of the diagram are EAP courses, which, as already stated, are focused only on languages. Between the two extremes, we have CLIL courses, which should have both language and content objectives. ICL and CBL would be located somewhere near CLIL, whether Immersion Programs would lean towards EMI. EMI courses have "content-related learning outcomes in their syllabuses"(Airey, 2016, p. 73), and language learning would be a byproduct, and not the main goal. However, Airey (2016) affirms that language and content cannot be separated in this way as they are totally connected. On top of these theoretical differences, it is the tendency to use the CLIL label to refer to the teaching of content and language in primary/secondary education, whereas EMI has been favored in HE in non-English dominant contexts.

EMI has expanded in Europe since the beginning of the Bologna Process in the 1990s. As a result, there has been a rapid increase in the number of programs from different European universities that adopted English as the language of instruction. Authors such as Dalton-Puffer (2012) and Macaro Akincioglu, and Dearden (2016) indicate the rapid global growth of EMI in the last decade. According to Bradford (2016), between 2001 and 2014 the number of EMI graduate and undergraduate programs around the world increased $1000 \%$. In order to map information around provision of EMI across a wide variety of programmes, courses and additional activities offered by Brazilian HEIs, a survey was sent to $270^{9}$ HEI (Gimenez et al., 2018). There were 84 responses to the questionnaire and 66 of them reported having some EMI activity in their campus. A more refined look at the data can be seen in table 2.

\begin{tabular}{|l|c|c|c|c|c|c|} 
& 2017 & 2018.1 & $2017-2018.1$ & $2018.2 / 2019$ & & AVERAGE \\
\cline { 4 - 8 } & & & & & & \\
\hline Full undergraduate programme & 1 & 1 & 2 & & 2 & (2017-2018.1) \\
\hline Full postgraduate programme & 5 & 5 & 10 & & 10 & 5 \\
\hline Undergraduate courses & 258 & 212 & 470 & 147 & 617 & 235 \\
\hline Postgraduate courses & 537 & 275 & 812 & 77 & 889 & 406 \\
\hline Extracurricular courses & & & 274 & 1 & 275 & 274 \\
\hline Not specified & & & & 7 & 7 & 90 \\
\hline Other activities in English & & & 90 & & 90 & 1,011 \\
\hline Sub-total - English & 801 & 493 & 1,294 & 228 & 1,890 & \\
\hline
\end{tabular}

\footnotetext{
${ }^{9}$ The 270 institutions are members of FAUBAI, the Higher Education Internationalization Association in Brazil. These are also the most important and prestigious HEI in the country, making it a significant sample.
} 
Table 2. Programmes, courses and activities in English and Portuguese for Foreigners courses. Retrieved from Gimenez et al. (2018).

Table 2 presents the type of activity offered in English ${ }^{10}$. What stands out is that only one full undergraduate program and five full graduate programs are offered in the country. With regards to courses, there were only 235 undergraduate and 406 graduate ones being taught in English. In spite of the low numbers, there was a substantial increase when compared to 2016, when there were only 197 undergraduate and 44 graduate courses in English (Gimenez et al., 2018). Overall, these results indicate that although EMI has been growing in Brazil, it is still in its embryonic stage. But why would EMI be important in a developing country such as Brazil?

Although EMI ${ }^{11}$ is mostly concerned with content, Muñoz (2012) points that the greater use of English contributes to establishing an environment that, indirectly, leads to language proficiency development. Individuals construct their dialogical relations in socially coconstructed practices using language (Clark, 1996) and, thus, English learning is grounded in interaction.

The adoption of EMI can bring considerable linguistic benefits because instructors and students can take part in authentic practices that require the use of English. This leads to an improvement in their proficiency for various practical purposes, such as the participation in academic events, Massive Open Online Courses (MOOCs), and exchanges with international research partners.

Authors such as Ammon (2010), Crystal (2012), De Swaan (2001), Montgomery (2013), Lillis and Curry (2010), and Solovova, Santos, and Verissimo (2018) have acknowledged that over the last decades the English language has achieved the status of global scientific and academic lingua franca ${ }^{12}$. English has become a key part of a myriad of knowledge production and practices in HE, acting as a key factor for the internationalization of the research and curriculum. For this reason, when used for teaching and learning in specific fields of study or in content-based programs, many factors need to be taken into consideration. Among these factors, instructors and students' different home languages, the language of the references adopted in the course, as well as the language used to interact outside the classroom.

It is, nonetheless, crucial to discuss what is meant by "language of instruction", since we believe in a paradigm where knowledge is not "transmitted" to students. Therefore, both teaching and learning happen through multiple interactions and collaborations inside and outside the classroom. Considering this, would "medium of instruction" be: (1) the language(s) spoken by the teacher, (2) the language(s) of the references, (3) the language(s) students use to interact with

\footnotetext{
${ }^{10}$ Data were also collected considering other ALs, however, these have not been made available yet.

${ }^{11}$ This paper focuses on the use of English as a Medium of Instruction. However, instruction in ALs other than English is also taking place in Brazil. In a recent seminar about initiatives to integrate language and content in tertiary education, a professor from the Federal University of Minas Gerais (UFMG) shared his experience offering a Philosophy course in German, and classes in French have also taken place in the same institution (see https://www.ufmg.br/dri/encontro-sobre-ingles-como-meio-de-instrucao-para-docentes-da-ufmg/).

12 The supremacy of English over other languages is historically related to the hegemonic power of Englishspeaking countries, as several authors indicate (Ammon, 2010, Phillipson, 2015). Such questions will not be explored here, since they are beyond the scope of this study.
} 
each other?, or (4) the language of video lessons? ${ }^{13}$. To illustrate the complexity of language and teaching phenomena, Baumvol and Sarmento (2016) based on discussions of Sarmento, Tessler and Baumvol (2015), present some potential configurations of the involvement of English and other ALs in teaching and learning practices in $\mathrm{HE}^{14}$.

\begin{tabular}{|c|c|c|c|}
\hline Configuration & $\begin{array}{l}\text { Instructor's } \\
\text { language }\end{array}$ & $\begin{array}{l}\text { Students' language and learning } \\
\text { language }\end{array}$ & Example \\
\hline 1 & L1 & $\begin{array}{l}\text { L1 to all students. } \\
\text { References in } \mathrm{AL} \\
\text { Students do assignments/take } \\
\text { exams in L1 }\end{array}$ & $\begin{array}{l}\text { A Brazilian instructor teaching Physics in Portuguese } \\
\text { to Brazilian students in Brazil using all references in } \\
\text { English. Students interact and do assignments/take } \\
\text { exams in Portuguese }\end{array}$ \\
\hline II & L1 & $\begin{array}{l}\text { L1 to all students } \\
\text { References in } A L \\
\text { Students do assignments/take } \\
\text { exams in } \mathrm{L} 1 \text { or in } \mathrm{AL}\end{array}$ & $\begin{array}{l}\text { A Brazilian instructor teaching Physics in Portuguese } \\
\text { to Brazilian students in Brazil using all references in } \\
\text { English. Students interact and do assignments/take } \\
\text { exams in Portuguese or English }\end{array}$ \\
\hline III & $\mathrm{L} 1$ & $\begin{array}{l}\text { AL to some students (same or } \\
\text { different L1) } \\
\text { L1 to some students }\end{array}$ & $\begin{array}{l}\text { A Brazilian instructor teaching Physics in Portuguese } \\
\text { to Brazilian and German students in Brazil }\end{array}$ \\
\hline IV & L1 & $\begin{array}{l}\text { AL to all students (students share } \\
\text { same L1) }\end{array}$ & $\begin{array}{l}\text { A British instructor teaching Physics in English to } \\
\text { Brazilian students in Brazil }\end{array}$ \\
\hline V & $\mathrm{L} 1$ & $\begin{array}{l}\text { AL to all students (students share } \\
\text { same L1) }\end{array}$ & $\begin{array}{l}\text { A British instructor teaching Physics in English to } \\
\text { Brazilian students in the U.K. }\end{array}$ \\
\hline VI & L1 & $\begin{array}{l}\text { AL to all students (students same } \\
\text { L1) }\end{array}$ & $\begin{array}{l}\text { A British instructor teaching Physics in English to } \\
\text { Brazilian students in France }\end{array}$ \\
\hline VII & $\mathrm{L} 1$ & $\begin{array}{l}\text { AL to some students (students } \\
\text { same or different L1) }\end{array}$ & $\begin{array}{l}\text { A British instructor teaching Physics in English to } \\
\text { Brazilian and German students in France }\end{array}$ \\
\hline VIII & L1 & AL to all students (different L1) & $\begin{array}{l}\text { A British instructor teaching Physics in English to } \\
\text { Brazilian and German students in France }\end{array}$ \\
\hline IX & LA & $\begin{array}{l}\text { AL to all students (same L1) } \\
\text { Students interact and do } \\
\text { assignments/take exams in L1 }\end{array}$ & $\begin{array}{l}\text { Brazilian instructor teaching Physics in English to } \\
\text { Brazilian students in Brazil. Students interact and do } \\
\text { assignments/take exams in Portuguese }\end{array}$ \\
\hline$x$ & $\mathrm{LA}$ & $\begin{array}{l}\text { AL to all students (same L1) } \\
\text { Students do assignments/take } \\
\text { exams in L1 or in AL }\end{array}$ & $\begin{array}{l}\text { Brazilian instructor teaching Physics in English to } \\
\text { Brazilian students in Brazil. Students interact and do } \\
\text { assignments/take exams in Portuguese or English }\end{array}$ \\
\hline $\mathrm{XI}$ & LA & $\begin{array}{l}\text { AL to all students (same L1) } \\
\text { Students do assignments/take } \\
\text { exams in AL }\end{array}$ & $\begin{array}{l}\text { Brazilian instructor teaching Physics in English to } \\
\text { Brazilian students in Brazil. Students interact and do } \\
\text { assignments/take exams in English }\end{array}$ \\
\hline
\end{tabular}

${ }^{13}$ In recent years, there has been a growing popularity of video lessons for learning and improving a broad range of knowledge and skills.

${ }^{14}$ In Table 2, L1 refers to the home or first language, while AL alludes to Additional Language. 


\begin{tabular}{|c|c|l|l|}
\hline XII & LA & L1 to all students & $\begin{array}{l}\text { British instructor teaching Physics in Portuguese to } \\
\text { Brazilian students in Brazil. }\end{array}$ \\
\hline XIII & LA & $\begin{array}{l}\text { AL to all students (students share } \\
\text { same L1, mas it's different from } \\
\text { instructor's L1) }\end{array}$ & $\begin{array}{l}\text { Brazilian instructor teaching Physics in English to } \\
\text { German students either in Brazil, or in Germany, or } \\
\text { in the U.K. or in France }\end{array}$ \\
\hline XIV & LA & $\begin{array}{l}\text { Al to all students (students share } \\
\text { same L1) }\end{array}$ & $\begin{array}{l}\text { Brazilian instructor teaching Physics in English to } \\
\text { British students either in Brazil, or in the U.K., or in } \\
\text { France }\end{array}$ \\
\hline XV & LA & LA to some students & $\begin{array}{l}\text { Brazilian instructor teaching Physics in English to } \\
\text { Brazilian and British students either in Brazil or in } \\
\text { the U.K. }\end{array}$ \\
\hline
\end{tabular}

Table 3. Potential Configurations of AL as a medium of instruction. Reprinted from Baumvol \& Sarmento (2016, p. 75-76).

As shown in Configurations I and II of Table 3, in Brazil some courses commonly adopt references in English while the teacher and the students, most of the time, speak Portuguese in class. In these situations, students may end up choosing to take the tests and/or do assignments in English (configuration II). Also, in fields such as Engineering, Medicine and Chemistry, the most important scientific journals and conferences are entirely in English.

It is reported that in Brazilian HE institutions the following educational-relationships are also taking place in both undergraduate and graduate courses: (A) a Brazilian instructor teaching in Portuguese for Brazilian and foreign students (Configuration III), (B) a foreign instructor teaching classes in English for Brazilian students (Configuration IV), (C) a Brazilian instructor teaching classes in English and students taking tests and/or do assignments in Portuguese (Configuration IX), or alternate between Portuguese and English (Configuration X), or even entirely in English (Configuration XI), and (D) a foreign instructor whose first language is not Portuguese teaches classes in Portuguese for Brazilian students (Configuration XII).

Configuration III, in particular, has become increasingly popular in HE due to an increase in academic mobility and in the number of students whose first language is not Portuguese, which includes indigenous ${ }^{15}$ and minority languages. For these students, Portuguese becomes the AL, while it remains L1 to the instructor and to the other Brazilian students.

Therefore, a "gradation" regarding the presence of English (or any other AL) in the teaching and learning process can be practiced in HE. It is not a binary issue of whether "there is" or "there is not" use of EMI, but rather a variety of contexts in which English can be used by more (or fewer) participants in more (or fewer) contexts and means within the same classroom.

\section{Conclusion}

Studies on integrated content and language instruction in non-English-dominant countries have traditionally been conducted in school settings, and they still represent most investigations

\footnotetext{
${ }^{15}$ Major affirmative actions in recent years have been giving indigenous students access to HE in the country. However, it is important to point out that Gimenez et al. (2018) found that only $0.3 \%$ of undergraduate students, $2 \%$ of master's students and $4 \%$ of $\mathrm{PhD}$ candidates are foreigners.
} 
in the field (Dalton-Puffer, Llinares, Lorenzo, \& Nikula 2014, Llinares \& Morton, 2017, Nikula, Dalton-Puffer \& Llinares, 2013). More recently, Asia (Byun et al., 2011; Hu, 2014, Li \& Ruan, 2015), Scandinavia (Airey, 2012, Jensen, Denver, Mees \& Werther, 2013, Ljsoland, 2011, Söderlundh, 2013) and Spain (Dafouz \& Sanchez, 2013, Vázquez \& Gastaud, 2013), where EMI practices in HE have been increasingly widespread, have emerged as important research scenarios. Nevertheless, there is still a need to conduct further studies approaching practical issues faced by students and instructors in academic and research activities conducted in English in those contexts.

In Brazil, as shown in Gimenez et al (2018), EMI has been adopted through isolated initiatives of faculty members. Frequently, these instructors have extensive expertise in their fields and insufficient opportunities for pedagogical training and teacher education throughout their careers on issues such as the relationship between content and language. Arnó-Macià and Mancho-Barés (2015), Bonnet (2012), Fortanet (2012), Murray and Nallaya (2016) and Vázquez (2014) examined successful collaborative experiences between instructors from different disciplines and language instructors in non-English-dominant contexts. In the Brazilian context, establishing these partnerships could maximize the learning of content and language by both students and content instructors, who will use English for a myriad of practical purposes while "at home". Undoubtedly, offering classes to improve general English literacy skills, as done in the Languages without Borders program, is essential to broaden the scope of EMI in a nonEnglish dominant context like Brazil and to ensure that EMI does not reinforce exclusion and inequality due to lack of language proficiency. However, it is our understanding that not providing more opportunities to use English and other ALs in Brazilian universities for students who do not have the means to take an English course abroad not only perpetuates social inequality but also helps to produce it. As discussed above, elite families make sure their children have this important symbolic and cultural capital (Bourdieu, 1986) which will enable them to function in the contemporary society. According to a teacher who had worked in a number of language courses,

The difference between upper-class students and poor students, is that English is already a part of the reality for the upper-class students. For the working class students, it is just a dream." (Windle \& Nogueira, 2014, p. 188)

Thus, as applied linguists, it is indeed our responsibility to counterpose neoliberal market forces which overemphasize the importance of the English language in detriment of others. Nevertheless, this cannot be done at the expense of working-class students, who have the right to learn ALs as much as those who come from wealthy families.

Finally, EMI can encourage a more balanced academic mobility, since institutions from non-English dominant countries will be more prepared to receive students from different geolinguistic regions of the globe. We find it crucial that Brazilian post-secondary students and faculty understand and express themselves in English, while preserving varied practices in Portuguese and in minority languages. A nation aiming to play a prominent role in the global scenario must have its scientific, academic and cultural results shared with a wider audience, and 
the English language would allow that. At the same time, Brazilians need direct and full access to international knowledge, which is predominantly produced and disseminated in English. Those who master this global language are much better prepared even to challenge its supremacy. This will allow the process of internationalization to be more aligned with the guiding principles and purposes established by international and national organizations and documents. 


\section{References}

Airey, J. (2012) “I don’t teach language” The linguistic attitudes of physics lecturers in Sweden. Aila Review, 25, 64-79.

Airey, J. (2016). Content and language integrated learning (CLIL) and English for academic purposes (EAP). In K. Hyland \& P. Shaw (Eds.), Routledge handbook of English for academic purposes (pp. 71-83). London: Routledge.

Ammon, U. (2010). English and other international languages under the impact of globalization. Neuphilologische Mitteilungen, 111(1), 9-28.

ANDIFES. (2012). Programa de Expansão, Excelência e Internacionalização das Universidades Federais. Retrieved from http://www.andifes.org.br/wpcontent/files_flutter/1360930928PEEXIU.pdf

Arnó-Macià, E., \& Mancho-Barés, G. (2015). The role of content and language in content and language integrated learning (CLIL) at university: Challenges and implications for ESP. English for Specific Purposes, 37, 63-73.

Bartlett, L. (2007). Literacy, speech and shame: The cultural politics of literacy and language in Brazil. International Journal of Qualitative Studies in Education, 20(5), 563-547.

Baumvol, L. K., \& Sarmento, S. (2016). A internacionalização em casa e o inglês como meio de instrução. In M. S.Beck, M. Moritz, M. Martins, \& V. Heberle (Eds.), ECHOES: Further Reflections on Language and Literature (pp. 65-82). Florianópolis: EdUFSC.

Baumvol, L. K., Sarmento, S., Welp, A., \& Bocorny, A. (2016). Understanding perceptions on EMI at a public higher education university in Brazil. Paper presented at 2016 FAUBAI Conference, Fortaleza, Brazil.

Beelen, J., \& Jones, E. (2015). Redefining internationalisation at home. In A. Curaj, L. Matei, R. Pricopie, J. Salmi, \& P. Scott (Eds.). The European higher education area: Between critical reflections and future policies (pp. 59-72). New York, NY: Springer.

Bonnet, A. (2012). Towards an evidence base for CLIL: How to integrate qualitative and quantitative as well as process product and participant perspectives in CLIL research. International CLIL Research Journal, 1(4), 65-78.

Bourdieu P. (1986). The forms of capital. In: J. G. Richardson (Ed.). Handbook of theory and research for the sociology of education (pp. 241-258). New York: Greenwood Press.

Bradford, A. (2016). Toward a typology of implementation challenges facing English-medium instruction in higher education: Evidence from Japan. Journal of Studies in International Education, 1-18.

British Council. (2016). EMI Summer School. Retrieved from https://www.britishcouncil.org.br/curso-emi/datas-locais/florianopolis

British Council. (2016). Guide of Brazilian higher education courses in English. Retrieved from https://www.britishcouncil.org/sites/default/files/guide_brazilian_highered_courses_inen glish_limpo_indexado_2.pdf

Byun K., Chu, J., Kim; M., Park, I., Kim, S., \& Jung, J. (2011). English-medium teaching in Korean Higher Education: policy debates and reality. Higher Education, 61, 431-449. 
Clark, H. H. (1996). The use of language. In H. H. Clark, Using language (pp. 3-25). Cambridge: Cambridge University Press.

Coleman, J. A. (2006). English-medium teaching in European higher education. Language Teaching, 39, 1-14.

Cooper, R. L. (1989). Language planning and social change. Cambridge, RU: Cambridge University Press.

Crystal, D. (2012). English as a global language. Cambridge: Cambridge University Press. 2012.

Dafouz, E. M., \& Sánchez, D. S. (2013). 'Does everybody understand?' Teacher questions across disciplines in English-mediated university lectures: an exploratory study. Language Value, 5(1), 129-151.

Dalton-Puffer, C. (2012). A postscript on institutional motivations, research concerns and professional implications. AILA Review, 25, 101-103.

Dalton-Puffer, C., Llinares, A., Lorenzo, \& F., Nikula, T. (2014). "You Can Stand Under My Umbrella": Immersion, CLIL and bilingual education. A Response to Cenoz, Genesee \& Gorter. Applied Linguistics, 35(2), 213-218.

De Swaan, A. (2001). Words of the world: The global language system. Cambridge: Polity Press. De Wit, H. (2002) Internationalization of higher education in the United States of America and Europe: A historical, comparative and conceptual analysis. Westport, CT: Greenwood Press.

De Wit, H., Hunter, F., Howard, L., \& Egron-Polak, E. (2015) (Eds.), Internationalisation of Higher Education. Brussels: European Parliament, Directorate-General for Internal Policies.

Dearden, J. (2015). English as a medium of instruction - A growing global phenomenon: phase 1. London, England: British Council. Retrieved from https://www.britishcouncil.org/sites/default/files/e484_emi__cover_option_3_final_web.pdf

Department of Education, Manitoba. (no date). Changing Terminology from ESL to EAL. Retrieved from http://www.edu.gov.mb.ca/k12/cur/eal/terminology.pdf

Egron-Polak, E. (2017) Academic mobility in Higher Education worldwide -Where are we? Where might we go in the future? [Powerpoint slides] Retrieved from http://eacea.ec.europa.eu/erasmus_mundus/events/10_years_erasmus_mundus/1.Presentat ion\%20Eva\%20Egron\%20Polak.pdf

European Commission (no date). The Bologna Process and the European Higher Education Area. Retrieved from http://ec.europa.eu/education/policy/higher-education/bolognaprocess_en

European Higher Education Area (n.d.). European Higher Education Area and the Bologna Process. Retrieved from http://www.ehea.info/pid34250/members.html European Parliament (2006). Multilingualism: An asset for Europe and a shared commitment. Bruxelas: European Union. Retrieved from http://eur-lex.europa.eu/legalcontent/EN/TXT/PDF/?uri=CELEX:52008DC0566\&from=en 
European Union (2009). The Bologna Declaration of 19 June 1999: Joint declaration of the European Ministers of Education. Retrieved from https://www.eurashe.eu/library/modernising-phe/Bologna_1999_BolognaDeclaration.pdf

European Union (2012). Treaty on the functioning of European Union. (Consolidated version). Bruxelles: European Union.

Fortanet, I. G. (2012) Academics' beliefs about language use and proficiency in Spanish multilingual higher education. Aila Review, 25, 48-63.

Garson, K. (2016). Reframing internationalization. Canadian Journal of Higher Education, 46(2), 19-39.

Gimenez, T., Sarmento, S., Archanjo, R., Zicman, R., \& Finardi, K. (2018). Guide to English as a medium of instruction in Brazilian Higher Education institutions 2018-2019. Retrieved from http://faubai.org.br/britishcouncilfaubaiguide2018.pdf

https://www.cbs.dk/files/cbs.dk/robert_philippson_the_business_of_english_global_panacea_or_ pandemic_0.pdf

Hu, G. (2014) English-medium instruction in Chinese higher education: A case study. Higher Education, 67(5), 551-567.

Instituto Nacional de Estudos e Pesquisas Educacionais Anísio Teixeira (2013). Resumos Técnicos. Retrieved from http://portal.inep.gov.br/web/censo-da-educacaosuperior/resumos-tecnicos

Jensen, C., Denver, L., Mees, I., \& Werther, C. (2013). Students' attitudes to lecturers' English in English-medium higher education in Denmark. Nordic Journal of English Studies, 13(1), 87-112.

Judd, E. L., Tan, L., \& Walberg, H. J. (2001). Teaching additional languages. Retrieved from http://unesdoc.unesco.org/images/0012/001254/125455e.pdf

Knight, J. (2008). Higher Education in Turmoil: The changing world of internationalization. Rotterdam: Sense Publishers.

Knight, J., \& de Wit, H. (Eds.) (1999). Quality and internationalization in higher education. Paris, France: OECD /IMHE.

Kostka, I., \& Olmstead-Wang, S. (2014). Teaching English for academic purposes. Annapolis Junction: TESOL Publishers.

Kubota, R. (2009). Internationalization of universities: Paradoxes and responsibilities. The Modern Language Journal, 93, 612-615.

Kubota, R. (2018). Unpacking research and practice in world Englishes and second language acquisition. World Englishes, 37, 93-105.

Kumaravadilevu, B. (2006). A Linguística aplicada na era da globalização. In L. P. Moita Lopes (Org.), Por uma linguística aplicada indisciplinar (pp. 129-148). São Paulo: Parábola.

Languages Canada. (2017). 2017 Annual Survey Report. Retrieved from https://www.languagescanada.ca/web/default/files/users/240/2017\%20annual\%20survey \%20final\%20files/LC_(2017)2018_AnnualSurvey_EN_ExecutiveSummary\%20copy.pdf 
Li, C., \& Ruan, Z. (2015). Changes in beliefs about language learning among Chinese EAP learners in an EMI context in Mainland China: A socio-cultural perspective. System, 55, 43-52.

Lillis, T. M., \& Curry, M. J. (2010). Academic writing in a global context: The politics and practices of publishing in English. Abingdon: Routledge.

Lima, D. C. (2011). Inglês em escolas públicas não funciona? Uma questão de múltiplos olhares [English in Public Schools Doesn’t Work? One Question, Multiple Perspectives]. São Paulo: Parábola.

Ljosland, R. (2011). English as an academic lingua franca: Language policies and multilingual practices in a Norwegian university. Journal of Pragmatics, 43, 991-1004.

Llinares, A., \& Morton, T. (2017). Applied linguistics perspectives on CLIL. Amsterdam: John Benjamins Publishing Company.

Macaro, E. (2017). English medium instruction: Global views and countries in focus: Introduction to the symposium held at the Department of Education, University of Oxford on Wednesday 4 November 2015. Language Teaching, 1-18.

Macaro, E., Akincioglu, \& M., Dearden, J. (2016). English medium instruction in universities: A collaborative experiment in Turkey. Studies in English Language Teaching, 4(1),

Marrara, T., \& Rodrigues, J. A. (2009). Medidas de internacionalização e o uso de idiomas estrangeiros. RBPG, 6(11), 121-143.

Ministério da Ciência, Tecnologia e Inovação (2011). Instituição do Programa Ciências sem Fronteiras. (Decreto $\mathrm{n}^{\mathrm{o}}$ 7642, de 13 de dezembro de 2011, Diário Oficial da União) Brasília: Brazil.

Ministério da Educação e Cultura (2012a). Instituição do Inglês sem Fronteiras (Portaria $\mathrm{n}^{\circ}$ 1.466, de 18 de dezembro de 2012, Diário Oficial da União, 28-29). Brasília: Brazil.

Ministério da Educação e Cultura (2012b). Idiomas sem Fronteiras. Retrieved from http://isf.mec.gov.br/

Ministério da Educação e Cultura (2014a) Plano Nacional de Educação. Planejando a próxima década conhecendo as 20 metas do Plano Nacional de Educação. Brasília: Ministério da Educação/Secretaria de Articulação com os Sistemas de Ensino (MEC/SASE).

Ministério da Educação e Cultura (2014b). Ciência Sem Fronteiras: O que é? Retrieved from http://www.cienciasemfronteiras.gov.br/web/csf/o-programa

Modern Language Association (2007). Foreign languages and Higher Education: New structures for a changed world. Retrieved from https://www.mla.org/flreport

Montgomery, S. (2013). Does science need a global language? English and the future of research. Chicago, IL: The University of Chicago Press.

Muñoz, C. (2012). Intensive exposure experiences in second language learning. UK: Multilingual Matters.

Murray, N., \& Nallaya, S. (2016) Embedding academic literacies in university programme curricula: A case study. Studies in Higher Education, 41(7), 1296-1312.

Nikula, T. (2007). Speaking English in Finnish content-based classrooms. World Englishes, 
26(2), 206-223.

Nikula, T. Dalton-Puffer, C., Llinares, A. (2013). European research on CLIL classroom discourse. Journal of Immersion and Content-Based Language Education, 1(1), 70-100.

OECD (2016). Education at a glance. Retrieved from http://www.oecd.org/edu/education-at-aglance-19991487.htm

Oliveira, G. M. (2016). Políticas linguísticas: uma entrevista com Gilvan Müller de Oliveira. ReVEL, 14(26), 382-399.

Phillipson, R. (2015). The business of English, global panacea or pandemic? Myths and realities of 'Global' English. Paper presented at 9th GEM\&L International Workshop on Management \& Language, Helsinki. Retrieved from

Rajagopalan, K. (2013). Políticas linguísticas: Do que é que se trata, afinal? In Nicolaides et al. (Orgs.), Política e Políticas Linguísticas (pp. 19-42), Campinas, SP: Pontes.

Rio Grande do Sul. (2009). Referenciais curriculares. Retrieved from http://servicos.educacao.rs.gov.br/dados/refer_curric_vol1.pdf

Rodrigues, A. D. (2005). Sobre as línguas indígenas e sua pesquisa no Brasil. Ciência e Cultura, 57(2), 35-38. Retrieved from http://cienciaecultura.bvs.br/scielo.php?script=sci_arttext\&pid=S0009$67252005000200018 \& \operatorname{lng}=\mathrm{en} \& \operatorname{tlng}=\mathrm{pt}$

Sarmento, S., Abreu-e-Lima, D. M., \& Moraes, W. B. (2016). Do Inglês sem Fronteiras ao Idiomas sem Fronteiras à construção de uma política linguística para a internacionalização. Belo Horizonte: Editora UFMG.

Sarmento, S., Tessler, L., \& Baumvol, L.K. (2015). English as a medium of instruction into practice. Paper presented at the 2015 FAUBAI Conference, Mato Grosso, MT, Brazil.

Shohamy, E. (2006). Language policies. Hidden agendas and new approaches. New York: Routledge.

Söderlundh, H. (2013). Applying transnational strategies locally: English as a medium of instruction in Swedish higher education. Nordic Journal of English Studies, 13(1), 113132.

Solovova, O., Santos, J.V., \& Verissimo, J. (2018). Publish in English or perish in Portuguese: Struggles and constraints on the semiperiphery. Publications, 6(2), 1-14.

Teekens, H. (2007). Internationalisation at home: An introduction. In H. Teekens (Org.). Occasional paper 20: Internationalisation at home: Ideas and ideals (pp. 3-12), Amsterdam: Drukkerij Raddraaier.

UNESCO (2009). World Conference on Higher Education 2009. Paris, France. Retrieved from http://unesdoc.unesco.org/images/0018/001892/189242e.pdf

UNESCO (2014). Item 29 of the provisional agenda on language teaching in education systems. Paris, France. Retrieved from http://unesdoc.unesco.org/images/0022/002272/227206e.pdf

UNESCO (n.d.). What is mobility? Retrieved from http://www.unesco.org/education/studyingabroad/what_is/mobility.shtml 
United Nations. (2016). UN and multilingualism. Retrieved from http://www.un.org/sg/multilingualism/index.shtml

Universidade Federal do Paraná. (May 9, 2016). Em parceria com Universidade de Oxford, professor da UFPR lança curso inédito para ministrar aulas em inglês. Retrieved from http://www.ufpr.br/portalufpr/blog/noticias/em-parceria-com-universidade-de-oxfordprofessor-da-ufpr-lanca-curso-inedito-para-ministrar-aulas-em-ingles/

Van Damme, D. (2001). Quality issues in the internationalisation of higher education. Higher Education, 41, 415-441.

Vázquez, V. P. (2014). Enhancing the quality of CLIL: Making the best of the collaboration between language teachers and content teachers. Encuentros, 23, 115-127.

Vázquez, V. P., Gastaud, M. (2013). Designing bilingual programmes for Higher Education in Spain: Organisational, curricular and methodological decisions. CLIL Research Journal, 2(1), 82-89.

Windle, J. \& Nogueira, M. A. (2015). The role of internationalisation in the schooling of Brazilian elites: Distinctions between two class fractions. British Journal of Sociology of Education, 36(1), 174-192. 